\title{
Economic Diversification in Sultanate of Oman amidst Oil crises
}

\author{
Dr.Soofi Asra Mubeen ${ }^{1}$, Dr.Anitha Ravi Kumar ${ }^{2}$, Ms.Qudsia Nazneen ${ }^{3}$ \\ 1,2 (Business Studies Department, Higher College of Technology, Muscat, Sultanate of Oman) \\ ${ }^{3}$ (Business Administration and Economic Department, Mazoon College, Muscat, Sultanate of Oman)
}

\begin{abstract}
The study aims to examine the affects of oil prices on economic growth in amidst oil crises in Sultanate of Oman and to find out economic diversification plans in Sultanate of Oman amidst oil crises. Descriptive research design was adopted for the present study. The data was collected through secondary sources and it is found that to diversify economy there must be some shift in economic plans and policies. Diversification is needed due to decline in oil prices as $80 \%$ of the country's economy is from Oil. To stabilize earnings and increase revenue of the country's economy diversification can be done by promoting industrial sector, market for non-oil products can be encouraged and marketing of tourism is also one of the alternatives to develop economy in Sultanate of Oman.
\end{abstract}

Keywords:Diversification,Economy, Economic growth,Oman, Oil crises.

\section{Introduction}

Sultanate of Oman's economy has seen tremendous growth continuously for the past 50 years. From the year 1999, it improved further due to increase in oil prices. Oil is the major source of income for the economy and more than $80 \%$ of the country's economy is from oil. In recent years, due to decline in the oil prices has slowed down the economy and the Government is taking several measures to improve its economy as per the data released by the National center for statistics and information Oman's gross domestic product declines 5\% to OMR 25.5 billion in the year 2016 and this fall in economy is due to drastic decrease in crude oil prices in the international markets ${ }^{\mathrm{i}}$ Oil exporting countries has faced major problems due to several fluctuations in oil prices. Countries whose main source of Income is through oil is facing several problems like slowdown of infrastructure projects, unemployment problems, public spending, etc., which in turn has crippled the economy as a whole. When the prices of oil increases, there will be increase in the spending by the Government to improve infrastructure facilities where as decrease in oil prices forces the oil exporting country to cut down its spending thereby affecting the whole country economy. Oman should try to adopt various diversification policies so as to reduce dependency on the oil revenue and the country can be protected from the risk incurring due to the change in oil prices. Sultanate of Oman has to focus on non-oil activities and there is growth of 0.6 percent at OMR 19,282.3 million in 2016 against OMR 19,170.7 million in the previous year which shows that the non-oil GDP is showing a gradual increase in growth as the government major focus on tourism, logistics and mining sectors. ${ }^{\text {ii }}$ The government must try to increase the contribution of non-petroleum activities to GDP within its plan to diversify sources of the national income.

\section{Literature Review}

Alameen,M.M.Y.,(2016) Studied by using historical, descriptive and deductive methodology to specify the valuable Norway experience in the Gulf countries by recognizing the reasons of success, principles and policies adopted by Norway and it also helps the GCC to take various steps to shift concentration from not only producing the oil but to diversifying the economy. Chris et.al.,(2015) attempted to find out how economic diversification will improve stable and feasible economic growth in Nigeria and found that to diversify the economy a very Significant fundamental change in economic policies and political will to apply such changes in policies. Data revealed that due to neglect of agriculture there was a constant depreciation in GDP of the country and concluded that there should be an urgent diversification of the Nigerian economy.

Shayah (2015) studied the contribution of non-oil exports to the economic diversification in UAE as it is one of the most diversified economies in Arab countries which do not rely completely on oil as it concentrates on other sectors to play a major role in the development of the country's economy in the form of Trade and Tourism. Marzovilla (2014) examined the extent to which GCC countries can bear the costs of monetary association in the light of the signs arising from the traditional optimal currency area theory and in the contest of the deep structural modifications that characterized their economies and concluded that the GCC countries should launch an exchange rate system that suits the new economyin both the cases whether they introduce the single currency or retain their national currencies.

Hvidt (2013) analyzed past records and future trends of economic diversification in the six Gulf Cooperation Council countries by using content analysis, probable future diversification trends are studied from 
current development plans and national vision published by GCC government and concluded that the prospects of economic diversification through refinement of difficult political economic reforms has suffered a noteworthy setback. Noh A (2013) explained Malaysia's potential to diversify its economy and to reduce its dependence on natural resources is determined by two elements and demonstrated that the late entry of commercial oil production and the preceding existence of a booming private sector made it easy for Malaysia to diversify its economy and elude overdependence on natural resources. He also argued in his paper that the path in order to expand economy Malaysia must follow diversification strategy.

Belwal R \&Belwal S., (2010) made a study on economic growth and tourism in the post oil Omani economy with three major techniques of strategic analysis viz. PESTEL framework, Porters diamond model and SWOT and revealed through analysis that Oman is at cross roads where there is a need to find out areas that will contribute to the economic development and growth. Two sectors which can help in mitigating the problem isTourism and real estate sectors. Tasie (2009) examined the effect of the diversification programmes in the $7^{\text {th }}$ five year development plan from 1996 to 2000 in Negara Brunei Darussalam. As per Labour force survey unemployment has increased to $4.9 \%$ in 1995 from $3.6 \%$ in 1981 to $4.7 \%$ in 1991 which has accounted for diversification by not depending on Oil and gas but also provided more job opportunities for the growing work force among the Nationals of Brunei.

\section{Objectives Of The Study}

1. To analyze the GDP of Oman and its trend value.

2. To examine the affects of oil prices on economic growth in amidst Oil crises in Sultanate of Oman.

3. To findout the economic diversification plans in Sultanate of Oman in amidst Oil crises

\section{Scope Of The Study}

The present study is an attempt to seek out how diversification of the country'seconomy will enrich stable and sustainable economic growth in Sultanate of Oman. The study focuses on Economic Diversification in Sultanate of Oman amidst Oil crises.

\section{Research Methodology}

Descriptive research design was used for the present study and the data were collected through secondary sources from internet, official sources and records, journal research articles.

\section{Results And Discussion}

Table no.1: Oman's Oil Prices (US \$/ Barrel)

\begin{tabular}{|l|r|r|r|r|r|}
\hline \multicolumn{1}{|c|}{ Month } & \multicolumn{1}{c|}{$\mathbf{2 0 1 1}$} & $\mathbf{2 0 1 2}$ & $\mathbf{2 0 1 3}$ & $\mathbf{2 0 1 4}$ & \multicolumn{1}{c|}{$\mathbf{2 0 1 5}$} \\
\hline January & 83.6 & 109.33 & 107.14 & 105.97 & 78.24 \\
\hline February & 88.93 & 107.41 & 106.16 & 107.88 & 61.01 \\
\hline March & 92.51 & 110.63 & 107.78 & 104.04 & 46.73 \\
\hline April & 100.39 & 117.32 & 111.21 & 105.04 & 56.21 \\
\hline May & 108.95 & 122.8 & 105.5 & 104.36 & 55.09 \\
\hline June & 116.51 & 117.29 & 101.81 & 104.99 & 58.68 \\
\hline July & 109.2 & 107.68 & 100.43 & 105.65 & 63.62 \\
\hline August & 107.84 & 94.42 & 100.21 & 108.08 & 61.84 \\
\hline September & 110.57 & 99.47 & 103.59 & 106.24 & 56.33 \\
\hline October & 105.1 & 109.05 & 106.96 & 102.23 & 47.88 \\
\hline November & 106.96 & 111.24 & 108.58 & 97.26 & 45.76 \\
\hline December & 104.88 & 108.67 & 106.7 & 86.96 & 46.03 \\
\hline Average (Jan. - Dec.) & 102.95 & 109.61 & 105.51 & 103.23 & 56.45 \\
\hline
\end{tabular}

Source: Ministry of Oil and Gas and National centre for Statistics and Information

Table no. 1 shows the oil prices in US\$ per barrel for the years 2011 to 2015. It was high during the year 2012 and it gradually declined and reached half the price of 56.45 in the year 2015 when compared with any of the previous year prices. Several Five year development plans have been devised by the Government in order to improve the economic growth, education and developing a skilled labour force to match the needs of the industry. The eighth development plan which ended in 2015 had key plans for diversification of the economy, development of labour intensive economic growth industries to provide more employment and to encourage the establishment of small and medium enterprises. This plan also included improvement of agriculture and fisheries to enhance rural employment and national food security. The Ninth five year plan (2016-2020) focuses on improving employment and diversification of the economy. Oman's vision 2020 which also gives importance to diversification and developing private industries was a step towards developing the economy as a whole. 
Table no.2: GDP growth and trend value

\begin{tabular}{|r|r|r|}
\hline Year & GDP growth(Current US Dollars) & Trend value \\
\hline 2000 & 19.51 & 12.04838 \\
\hline 2001 & 19.45 & 16.79301 \\
\hline 2002 & 20.14 & 21.53765 \\
\hline 2003 & 21.63 & 26.28228 \\
\hline 2004 & 24.76 & 31.02691 \\
\hline 2005 & 31.08 & 35.77154 \\
\hline 2006 & 37.22 & 40.51618 \\
\hline 2007 & 42.09 & 45.26081 \\
\hline 2008 & 60.91 & 50.00544 \\
\hline 2009 & 48.39 & 54.75007 \\
\hline 2010 & 58.64 & 59.49471 \\
\hline 2011 & 69.52 & 64.23934 \\
\hline 2012 & 77.5 & 68.98397 \\
\hline 2013 & 79.66 & 73.7286 \\
\hline 2014 & 81.8 & 78.47324 \\
\hline 2015 & 69.83 & 83.21787 \\
\hline 2016 & & 87.9625 \\
\hline 2017 & & 92.70713 \\
\hline 2018 & & 97.45176 \\
\hline 2019 & & 102.1964 \\
\hline 2020 & & 106.941 \\
\hline
\end{tabular}

Source: Ministry of Oil and Gas and National centre for Statistics and Information

GDP in current US\$ and its trend value is shown in Table no.2. Trend value and actual value of GDP was almost the same until the year 2014, but in 2015 the actual value is only US\$ 69.83 when compared to the trend value of 83.21 which is due to the low oil prices which prevailed in that year.

\section{Diversification Plans Of Sultanate Of Oman}

Sultanate's diversification plans includes: Infrastructure development and Tourism development. This already has started to produce positive results with more than 2 million tourists visiting Oman during the year 2016 which helped to boost the economy. In addition to this, the Government is giving more importance to entrepreneurship development to bring out the talents and provide better opportunities to the Omanis instead of depending upon employment.

Table no. 3: Annual growth of GDP (\%) and Share of petroleum and Non-petroleum activities

\begin{tabular}{|l|r|r|r|r|r|}
\hline \multicolumn{1}{|c|}{ Items } & $\mathbf{2 0 1 1}$ & $\mathbf{2 0 1 2}$ & $\mathbf{2 0 1 3}$ & $\mathbf{2 0 1 4}$ & $\mathbf{2 0 1 5}$ \\
\hline GDP at current market price (R.O. Million) & 26122 & 29353.3 & 30061.3 & 31450.8 & 27013.1 \\
\hline Annual Growth (\%) & 15.9 & 12.4 & 2.4 & 4.6 & -4.1 \\
\hline Share in GDP at Current Market Price (in per cent) & & & & & \\
\hline 1. Petroleum Activities & 53.2 & 52.3 & 50.6 & 47.2 & 33.9 \\
\hline 2. Non-Petroleum activities & 54 & 54.6 & 57.2 & 60.2 & 71.7 \\
\hline
\end{tabular}

Source: Ministry of Oil and Gas and National centre for Statistics and Information

From the table no.3, we can understand that annual growth (\%) according to GDP current market price was high $(15.9 \%)$ during the year 2011. It reduced consistently and in 2015, it was (-4.1\%). Contribution of petroleum activities is continuously decreasing due to decrease in oil prices. Due to less oil prices GDP growth rate is also less. In order to overcome the difficulties faced the Government is trying to implement various diversification measures like:

1. Promoting small and medium scale industries

2. Improvement of Agriculture and fisheries

3. Tourism development

In spite of all these efforts, diversification of the economy remains in its nascent stage and the economic dependence on oil has not come down amidst low oil prices. Diversification in Oman has not achieved its expected results due to the following:

1. Lack of trained labour force available in the market in order to attract foreign direct investment

2. Low productivity of local labour force

3. Omanisation policy which prevents low cheap foreign labour to be recruited

4. Labour force not meeting the demands of private sector expectations

The above mentioned issues pose a major threat to the success of diversification of the economy. An effort has been made to study the affect of decrease in oil prices on the economy and the diversification measures taken by the Government to reduce its dependence on oil. 


\section{Conclusion}

As the Oman economy is dependent on Oil which is the main contributor to government revenues it has to take some plans and policies on development of new technology, diversification of the economy, controlling of inflation, undertaking unemployment and must try to diversify the economy and develop the country. Diversification is needed to stabilize earnings and increase the revenue of the whole economy. Diversification can be done by promoting industrial sector to increase their output by satisfying the demand in the local market as well as making large export which in turn increase the economy as a whole. Government can also help in promoting and attracting foreign direct investments. Infrastructure need to be upgraded and Financial restructuring i.e. interest rates need to be moderate so that it helps the private entrepreneurs to take loan and the market for non-oil products can be encouraged. Marketing of tourism can also be one of the alternatives to develop economy.

\section{Bibliography And References}

[1] AlameenMohammad,M.Yousif, The Norwegian oil experience of economic diversification:A comparative study with Gulf Oil, European Journal of Business and Management. Vol.8,no.15, 2016, 94-101.

[2] Chris Ifeanyi.O, Amujiri,A.B, Ndibe,B. N, Diversification of the economy: A panacea for Nigerian economic development. International Journal of Multidisciplinary Research and Development. Vol.2, Issues.5, 2015, 477-483.

[3] Shayah,H.M, Economic Diversification by boosting non-oil exports (Case of UAE). Journal of Economics, Business and Management, Vol.3, No.7, 2015, 735-738.

[4] Marzoviall.O, Economic Diversification in GCC countries and the optimality of a monetary union. European Scientific Journal.Special edition Vol 1, 2014, 658-675.

[5] Hvidt.M, Economic Diversification in GCC countries: Past record and Future trends. Research paper, Kuwait programme on Development, Governance and Globalization in the Gulf States.No.27, 2013, 1-49.

[6] Noh Abdillah, Natural Resources and Economic Diversification. A case of Malaysia.Tun Abdul Razak School of Government. Working Paper No: 2013/02.

[7] Belwal. R,\&Belwal. S, Economic growth and tourism in the post oil Omani economy: Astrategic analysis. Journal of Tourism Challenges and Trends, 3.1, 2010, 165-187.

[8] Tasie, O. George, Globalization and economic diversification in the Sultanate of Brunei. African Journal of Business Management.Vol. 3 (10),2009, 511-520.

[9] www.cbo-oman.org

\footnotetext{
${ }^{\mathrm{i}}$ April $24^{\text {th }} 2017$, Times of Oman news paper

ii April $24^{\text {th }} 2017$, Times of Oman news paper
} 